\title{
Polyphasic analysis in the description of Sulfitobacter salinus sp. nov., a marine alphaproteobacterium isolated from seawater
}

\author{
Jaewoo Yoon ${ }^{1}$ \\ Received: 22 April 2019 / Accepted: 11 September 2019/Published online: 14 October 2019 \\ (C) Università degli studi di Milano 2019
}

\begin{abstract}
Purpose A polyphasic analysis was performed on a novel bacterium, designated strain KMU-143 ${ }^{\mathrm{T}}$, which was isolated from seawater collected in the Republic of Korea.

Methods A novel marine bacterium KMU- $143^{\mathrm{T}}$ was analyzed and described using a polyphasic taxonomic method including 16S rRNA gene sequence analysis, DNA-DNA hybridization, and physiological, biochemical, and chemotaxonomic analyses. Results Strain KMU- $143^{\mathrm{T}}$ was Gram-stain-negative, strictly aerobic, oval-shaped, non-motile, and chemoorganoheterotrophic. Phylogenetic analysis based on the 16S rRNA gene sequence demonstrated that the novel marine bacterium belongs to the family Rhodobacteraceae, of the class Alphaproteobacteria, and that it possessed the highest (97.1\%) sequence similarity with Sulfitobacter pontiacus ChLG $10^{\mathrm{T}}$ and Sulfitobacter undariae W-BA2 ${ }^{\mathrm{T}}$. DNA-DNA relatedness values between strains KMU- $143^{\mathrm{T}}$, S. pontiacus JCM $21789^{\mathrm{T}}$, and $S$. undariae KCTC $42200^{\mathrm{T}}$ were less than $70 \%$. The major isoprenoid quinone of the novel isolate was ubiquinone-10 (Q-10) and the major (> 10\%) cellular fatty acids were $\mathrm{C} 16: 0$ and $\mathrm{C} 18: 1 \omega 7 c$. The genomic DNA G+C content of strain KMU-143 ${ }^{\mathrm{T}}$ was $56.1 \mathrm{~mol} \%$. The polar lipid profile of the strain KMU-143 ${ }^{\mathrm{T}}$ was found to consist of phosphatidylglycerol, diphosphatidylglycerol, phosphatidylcholine, an unidentified aminolipid, and two unidentified lipids.

Conclusion Based on the discriminative phylogenetic position and combination of genotypic and phenotypic properties, the strain is considered to represent a new species of the genus Sulfitobacter for which the name Sulfitobacter salinus sp. nov. is proposed. The type strain of S. salinus sp. nov. is $\mathrm{KMU}_{-143^{\mathrm{T}}}\left(=\mathrm{KCCM} 90322^{\mathrm{T}}=\mathrm{NBRC} 113459^{\mathrm{T}}\right)$.
\end{abstract}

Keywords Alphaproteobacteria $\cdot$ Sulfitobacter salinus sp. nov. · Seawater $\cdot 16$ S rRNA gene $\cdot$ Polyphasic taxonomy

\section{Introduction}

The class Alphaproteobacteria (Stackebrandt et al. 1988; Garrity et al. 2005) is one of the main phylogenetic lineages among the marine bacterioplankton, along with species of the class Gammaproteobacteria and the phylum Bacteroidetes (Giovannoni and Rappé 2000). In particular, this class

The digital protologue database (DPD) number for the strain KMU-143 is TA00838. The GenBank/EMBL/DDBJ accession number of the $16 \mathrm{~S}$ rRNA gene sequence of strain KMU-143 ${ }^{\mathrm{T}}$ is LC464517.

Electronic supplementary material The online version of this article (https://doi.org/10.1007/s13213-019-01515-1) contains supplementary material, which is available to authorized users.

Jaewoo Yoon

jwyoon@kmu.ac.kr

1 College of Pharmacy, Keimyung University, 1095 Dalgubeoldaero, Dalseo-Gu, Daegu 42601, Republic of Korea comprises heterogeneous and various phylogenetic groups with diverse microbial properties and thought to carry out significant environmental roles (Giovannoni and Rappé 2000). The genus Sulfitobacter, a member of the family Rhodobacteraceae within the class Alphaproteobacteria, was first formally established by Sorokin (1995) to describe a sulfur-oxidizing chemoheterotrophic type species isolated from the Black Sea with Sulfitobacter pontiacus ChLG $10^{\mathrm{T}}$. An emended description of the genus was later presented by Yoon et al. (2007). At the time of writing, the genus Sulfitobacter includes nineteen validly named species (http:// www.bacterio.net/sulfitobacter.html), which were isolated from a variety of marine ecosystems such as Antarctic lake (Labrenz et al. 2000), seawater (Park et al. 2007; Sorokin 1995; Kwak et al. 2014), tidal flat sediment (Park et al. 2018), and marine organisms (Fukui et al. 2015; Hong et al. 2015; Kumari et al. 2016). In 2018, in the course of screening the culturable marine microorganisms from diverse marine environments, a bacterium designated KMU- $143^{\mathrm{T}}$ was 
isolated from the seawater collected at Hamdeok Beach in Jeju Island. In the present study, a novel marine bacterium KMU$143^{\mathrm{T}}$ was analyzed and described using a polyphasic taxonomic method (Colwell 1970) including 16S rRNA gene sequence analysis, DNA-DNA hybridization, and physiological, biochemical, and chemotaxonomic analyses. On the basis of data from this polyphasic taxonomic approach, the novel isolate is suggested to represent a new species of the genus Sulfitobacter within the class Alphaproteobacteria.

\section{Materials and methods}

\section{Isolation of the bacterial strain and culture condition}

The seawater sample was collected at Hamdeok Beach, Jeju Island, Republic of Korea (GPS data, $33^{\circ} 32^{\prime} 36.6^{\prime \prime} \mathrm{N} 126^{\circ} 40^{\prime}$ 10.5" E), in April 2018 by use of a $500 \mathrm{~mL}$ sterile polyethylene bottle. A 50- $\mu \mathrm{L}$ aliquot of the sample was plated onto the surface of marine agar 2216 (Difco). Several colonies that developed at $25{ }^{\circ} \mathrm{C}$ were then picked and re-streaked onto new marine agar 2216 plates, and the procedure was repeated twice. A beige-colored colony was picked as a representative of morphologically similar colonies, named KMU- $143^{\mathrm{T}}$, and was used for further analysis. For comparative purpose, Sulfitobacter pontiacus JCM $21789^{\mathrm{T}}$ and Sulfitobacter undariae KCTC $42200^{\mathrm{T}}$ were used as reference strains. $\mathrm{KMU}-143^{\mathrm{T}}$ and the reference strains were routinely subcultured on marine agar 2216 at $25{ }^{\circ} \mathrm{C}$ and maintained in marine broth 2216 (Difco) supplemented with $40 \%$ (v/v) glycerol at $-80^{\circ} \mathrm{C}$.

\section{Morphological, physiological, and biochemical analysis}

The bacterial cell shape was observed via transmission electron microscopy (TEM) and scanning electron microscopy (SEM). Cell motility was investigated by phase-contrast microscopy (Primo Star, Zeiss). For TEM analysis, cells were grown on marine agar 2216 at $25{ }^{\circ} \mathrm{C}$ for 3 days, loaded onto glow-discharged EM grids covered with a continuous carbon film, and negatively stained with $1 \%(\mathrm{w} / \mathrm{v})$ uranyl acetate. The grids were observed using a Tecnai G2 Spirit (FEI) transmission electron microscope (Korea Basic Science Institute) at $120 \mathrm{kV}$ with a magnification of $\times 21,000$; SEM analysis was performed by previously established methods (Schädler et al. 2008; Wang et al. 2015). The temperature range $(4,10,15,20$, $25,30,37,40$, and $45^{\circ} \mathrm{C}$ ) and $\mathrm{pH}$ range (5.5-9.5 at increments of $0.5 \mathrm{pH}$ ) for growth were tested by incubating the isolate for 1 week on marine agar 2216. The $\mathrm{pH}$ tests were performed with the buffers prepared by previously reported method (Yoon et al. 2016). The $\mathrm{NaCl}$ concentration for growth was examined on TY agar medium [1\% tryptone, $0.3 \%$ yeast extract, $0.9 \% \mathrm{MgCl}_{2} \cdot 6 \mathrm{H}_{2} \mathrm{O}, 0.9 \% \mathrm{MgSO}_{4} \cdot 7 \mathrm{H}_{2} \mathrm{O}, 0.2 \%$ $\mathrm{CaCl}_{2} \cdot 2 \mathrm{H}_{2} \mathrm{O}, 0.06 \% \mathrm{KCl}$, and $1.5 \%$ agar (w/v) with $0-10 \%$ $(\mathrm{w} / \mathrm{v}) \mathrm{NaCl}$ (at increments of 1\%)], and the cells were grown at $25^{\circ} \mathrm{C}$. Gram-staining assay was performed using the BD Gram-Staining Kit (Becton, Dickinson and Company, USA). Anaerobic growth was assessed for up to 2 weeks on marine agar 2216 in a jar containing the AnaeroPack-Anaero (Mitsubishi Gas Chemical), which can act as an $\mathrm{O}_{2}$ absorber and $\mathrm{CO}_{2}$ generator. Catalase activity was tested by bubble formation in $3 \%(\mathrm{v} / \mathrm{v}) \mathrm{H}_{2} \mathrm{O}_{2}$ solution. An oxidase activity was tested using a commercialized dropper oxidase reagent (Becton Dickinson and Company, Sparks, MD, USA). DNase activity was examined using marine agar 2216 containing $0.2 \%$ DNA and $0.005 \%$ methyl green (Hansen and Sørheim 1991). Casein hydrolysis was evaluated on marine agar 2216 containing $0.1 \%$ skim milk (Power and Johnson 2009). A tyrosine degradation was tested according to the previously described method (Lewin and Lounsbery 1969). The ability to hydrolyze Tween 20 and 80 was tested based on Hansen and Sørheim's method (1991). API 20E, API 50CH, and API ZYM strips (bioMérieux) were utilized to evaluate physiological and biochemical properties. All the media for the API test strips were supplemented with $\mathrm{NaCl}$ solution (final concentration $0.85 \%$, w/v). The API $20 \mathrm{E}$, API $50 \mathrm{CH}$, and API ZYM strips were incubated at $25^{\circ} \mathrm{C}$ for 3 days, 9 days, and $3 \mathrm{~h}$, respectively, and the results were interpreted according to the manufacturer's instructions. The hydrolysis of gelatin and urea as well as nitrate reduction was assessed using the API $20 \mathrm{E}$ strip. The hydrolysis of agar and starch was tested using marine agar 2216 and the API 50CH strip, respectively. Utilization of organic substrates as sole carbon and energy sources was evaluated using Biolog GEN III MicroPlate systems (Biolog) according to the manufacturers' instructions.

\section{Determination of DNA G+C content, 16S rRNA gene sequencing, and phylogenetic analysis}

Extraction of the genomic DNA was performed using the Wizard® Genomic DNA Purification Kit (Promega) according to the manufacturer's instructions, and cells were harvested from marine agar 2216 plates after 3 days of incubation at $25^{\circ} \mathrm{C}$. The DNA base composition was determined using the HPLC method of Mesbah et al. (1989). The genomic DNA $\mathrm{G}+\mathrm{C}$ content was calculated in triplicate. The $16 \mathrm{~S}$ rRNA gene was PCR-amplified from the extracted DNA using a bacterial universal primer set specific to the $16 \mathrm{~S}$ rRNA gene: $27 \mathrm{~F}$ and 1492R (Lane 1991). The amplified PCR product was purified using a PCR purification kit (BIOFACT) and sequenced directly by the fluorescent dye-terminator method using an $\mathrm{ABI}$ 3730XL Capillary DNA Analyzer (Applied Biosystems) at BIOFACT Co., Ltd (Daejeon, Korea). The almost full-length 16S rRNA gene sequence was compiled using the SeqMan software (DNASTAR). Sequence similarities of the $16 \mathrm{~S}$ 
rRNA gene were determined using the EzBioCloud database (https://www.ezbiocloud.net/) (Yoon et al. 2017). To elucidate the phylogenetic position of the novel bacterium, the $16 \mathrm{~S}$ rRNA gene sequence of strain KMU-143 ${ }^{\mathrm{T}}$ was compared with the sequences obtained from GenBank/EMBL/DDBJ database. Multiple alignments of the sequences were performed using CLUSTAL_X (version 1.83) (Thompson et al. 1997). Phylogenetic distances (distance options according to Kimura's two-parameter model; Kimura 1980) were calculated, and clustering was performed with the neighbor-joining (Saitou and Nei 1987), maximum-parsimony (Fitch 1971), and maximum-likelihood (Felsenstein 1985) algorithms using the MEGA5 software (Tamura et al. 2011). The topology of the evolutionary tree was calculated by the bootstrap resampling method of Felsenstein (1985) with 1000 replicates.

\section{DNA-DNA hybridization test}

Chromosomal DNA was extracted using the Wizard® Genomic DNA Purification Kit (Promega) following the manufacturer's instructions. DNA-DNA hybridization was performed by the membrane filter method (Suzuki et al. 1981). Each mixture of labeled and unlabeled DNAs was incubated at $37{ }^{\circ} \mathrm{C}$ for $12 \mathrm{~h}$. Reciprocal hybridization tests were performed in triplicate.

\section{Chemotaxonomic analysis}

Gas chromatographic analysis of the cellular fatty acid methyl esters (FAMEs) was performed using the MIDI TSBA database (version 6.1) (Sasser 1990). Strain KMU$143^{\mathrm{T}}$ and the reference strains were cultured on marine agar 2216 at $25{ }^{\circ} \mathrm{C}$ for 3 days for the FAMEs analysis. Polar lipids were extracted according to the procedures described by Minnikin et al. (1984). They were identified by twodimensional thin-layer chromatography followed by spraying with the appropriate detection reagents (Minnikin et al. 1984; Komagata and Suzuki 1987). Whole lipids were detected by spraying with $5 \%$ molybdatophosphoric acid (5 g molybdatophosphoric acid hydrate in $100 \mathrm{~mL}$ ethanol) followed by heating at $150{ }^{\circ} \mathrm{C}$ (Worliczek et al. 2007). Phospholipids were detected by spraying with $1.4 \%$ molybdenum blue. Glycolipids were detected by spraying with $2.5 \% \alpha$-naphthol followed by heating at $180{ }^{\circ} \mathrm{C}$. Aminolipids were detected by spraying with $0.2 \%$ ninhydrin followed by heating at $180{ }^{\circ} \mathrm{C}$. Quinones were extracted from freeze-dried cells with chloroform/methanol $(2: 1, \mathrm{v} / \mathrm{v})$. Samples were eluted with methanol/isopropyl ether $(4: 1, \mathrm{v} / \mathrm{v})$ at a flow rate of $1 \mathrm{~mL}$ $\mathrm{min}^{-1}$. Analysis of the respiratory quinone system was performed as described previously (Collins and Jones 1981).

\section{Results and discussion}

\section{Morphological, physiological, and biochemical properties}

The discriminative phenotypic properties of strain KMU-143 ${ }^{\mathrm{T}}$ are shown in Table 1 and in the species description. Cells of strain KMU-143 ${ }^{\mathrm{T}}$ grown on marine agar 2216 were mostly oval-shaped with $0.9-1.0 \mu \mathrm{m}$ in width and $1.0-1.2 \mu \mathrm{m}$ in length (Fig. 1a, b). The bacterial cells did not have flagella or appendages (Fig. 1a, b) and produced a beige pigment. Observation of a SEM image indicated that the novel strain reproduces by binary fission (Fig. 1b). Strain KMU-143 ${ }^{\mathrm{T}}$ was distinguished from the most closely related species by observing main characteristics such as motility (negative), acid production (positive for 5-keto-gluconate), enzyme activity [positive for esterase (C4) and negative for acid phosphatase, arginine dihydrolase, $\alpha$-galactosidase, lysine decarboxylase, ornithine decarboxylase, and valine arylamidase], and utilization of organic substrates (positive for citric acid and negative for $N$-acetylneuraminic acid, $N$-acetyl-D-galactosamine, $N$ acetyl- $\beta$-D-mannosamine, $\gamma$-aminobutyric acid, L-arginine, L-aspartic acid, dextrin, D-gluconic acid, D-glucuronic acid, L-glutamic acid, $\alpha$-hydroxybutyric acid, inosine, D-malic acid, and pectin) (Table 1).

\section{Determination of DNA G+C content, phylogenetic analysis, and DNA-DNA hybridization}

The G+C content of the genomic DNA of the type strain KMU- $143^{\mathrm{T}}$ was 56.1 mol\%. Furthermore, the almost complete $16 \mathrm{~S}$ rRNA gene sequence (1404 bp) was determined for the novel strain. An evolutionary tree on the basis of the neighbor-joining algorithm was generated for a visual comparison of $16 \mathrm{~S}$ rRNA gene sequences and revealed that strain KMU-143 ${ }^{\mathrm{T}}$ was phylogenetically affiliated with Sulfitobacter, a genus belonging to the family Rhodobacteraceae, of the class Alphaproteobacteria (Fig. 2). A comparative phylogenetic investigation based on the $16 \mathrm{~S}$ rRNA gene sequences revealed that strain KMU- $143^{\mathrm{T}}$ had a similarity of $97.1 \%$ to S. pontiacus ChLG $10^{\mathrm{T}}$ and $S$. undariae $\mathrm{W}-\mathrm{BA} 2^{\mathrm{T}}, 96.9 \%$ to Sulfitobacter donghicola DSW-25 ${ }^{\mathrm{T}}$, and $96.8 \%$ to Sulfitobacter guttiformis EL-38 ${ }^{\mathrm{T}}$. 16S rRNA gene sequence similarities to all other species of the family Rhodobacteraceae with validly published names were less than $96.5 \%$. The overall phylogenetic tree topologies calculated using the maximum-parsimony and maximumlikelihood methods also supported the neighbor-joining tree (Fig. 2). DNA-DNA hybridization values between strain KMU $-143^{\mathrm{T}}$ and strains S. pontiacus JCM $21789^{\mathrm{T}}$ and S. undariae KCTC $42200^{\mathrm{T}}$ were $9.9 \pm 1.0 \%$ and $10.5 \pm$ $2.0 \%$, respectively. These values are sufficient to classify strain KMU- $143^{\mathrm{T}}$ as a novel species that is distinct from the 
Table 1 Discriminative properties of strain KMU-143 ${ }^{\mathrm{T}}$ and closely related species

\begin{tabular}{|c|c|c|c|}
\hline Characteristic & 1 & 2 & 3 \\
\hline Isolation source & Seawater & Seawater ${ }^{\mathrm{a}}$ & Brown algae reservoir $^{\mathrm{b}}$ \\
\hline Cell morphology & Oval-shaped & Rod-shaped $^{\mathrm{a}}$ & $\begin{array}{l}\text { Coccoid, ovoid, } \\
\text { or rod-shaped }^{\mathrm{b}}\end{array}$ \\
\hline Motility & - & $t^{\mathrm{a}}$ & $-{ }^{\mathrm{b}}$ \\
\hline \multicolumn{4}{|l|}{ Growth conditions for } \\
\hline Temperature $\left({ }^{\circ} \mathrm{C}\right)$ & $10-37(25)$ & $4-35(22-25)^{\mathrm{a}}$ & $4-30(25)^{b}$ \\
\hline $\mathrm{pH}$ & $6.5-9.5(7.5)$ & $6.5-8.5(7.3-7.5)^{\mathrm{a}}$ & $5.5-8.0(7.0-8.0)^{\mathrm{b}}$ \\
\hline $\mathrm{NaCl}(\%, \mathrm{w} / \mathrm{v})$ & $1.0-6.0(2.0)$ & $0.5-8.0(2.0-2.5)^{\mathrm{a}}$ & $0-10.0(2.0-3.0)^{\mathrm{b}}$ \\
\hline \multicolumn{4}{|l|}{ Reaction of } \\
\hline Voges-Proskauer & - & + & + \\
\hline \multicolumn{4}{|l|}{ Hydrolysis of: } \\
\hline $\begin{array}{l}o \text {-Nitrophenyl- } \beta \text {-D- } \\
\text { galactopyranoside (ONPG) }\end{array}$ & + & + & - \\
\hline \multicolumn{4}{|l|}{ Acid production from } \\
\hline 5-Keto-gluconate & + & + & - \\
\hline \multicolumn{4}{|l|}{ Enzyme activity of: } \\
\hline Acid phosphatase & - & + & + \\
\hline Arginine dihydrolase & - & + & - \\
\hline Esterase (C4) & + & - & - \\
\hline$\alpha$-Galactosidase & - & + & - \\
\hline Lysine decarboxylase & - & + & - \\
\hline Ornithine decarboxylase & - & + & - \\
\hline Valine arylamidase & - & - & + \\
\hline \multicolumn{4}{|l|}{ Utilization of } \\
\hline$N$-Acetylneuraminic acid & - & + & + \\
\hline$N$-Acetyl-D-galactosamine & - & + & + \\
\hline$N$-Acetyl- $\beta$-D-mannosamine & - & + & + \\
\hline$\gamma$-Aminobutyric acid & - & + & + \\
\hline L-Arginine & - & + & + \\
\hline L-Aspartic acid & - & + & + \\
\hline Citric acid & + & - & - \\
\hline Dextrin & - & + & + \\
\hline D-Gluconic acid & - & + & + \\
\hline D-Glucuronic acid & - & + & + \\
\hline L-Glutamic acid & - & + & + \\
\hline$\alpha$-Hydroxybutyric acid & - & + & + \\
\hline Inosine & - & + & + \\
\hline D-Malic acid & - & + & + \\
\hline Pectin & - & + & + \\
\hline Polar lipids & $\begin{array}{l}\text { PG, DPG, } \\
\quad \text { PC, AL, 2L }\end{array}$ & $\begin{array}{l}\text { PE, PG, DPG, } \\
\text { PC, AL, 3L }\end{array}$ & $\begin{array}{l}\text { PE, PG, DPG, } \\
\text { PC, AL, 2L }\end{array}$ \\
\hline DNA G+C content $(\mathrm{mol} \%)$ & 56.1 & $62.1^{\mathrm{a}}$ & $55.0^{\mathrm{b}}$ \\
\hline
\end{tabular}

Strains: 1 KMU-143 ${ }^{\mathrm{T}}$ (Sulfitobacter salinus sp. nov.; present study), 2 Sulfitobacter pontiacus $\mathrm{JCM} 21789^{\mathrm{T}}, 3$ Sulfitobacter undariae KCTC $42200^{\mathrm{T}}$

All data are from this study except where indicated otherwise. Numbers in parentheses are optimal growth conditions

$P E$ phosphatidylethanolamine, $P G$ phosphatidylglycerol, $D P G$ diphosphatidylglycerol, $P C$ phosphatidylcholine, $A L$ unidentified aminolipid, $L$ unidentified lipid

+ , positive; -, negative

${ }^{\text {a }}$ Data from Sorokin 1995

${ }^{\mathrm{b}}$ Data from Park et al. 2015 
Fig. 1 Transmission electron micrograph of a negatively stained cell of strain KMU-143 ${ }^{\mathrm{T}}$ (a). Scanning electron micrograph of strain KMU-143 ${ }^{\mathrm{T}}$ (b). Bars, $1 \mu \mathrm{m}$ (a) and $3 \mu \mathrm{m}$ (b)
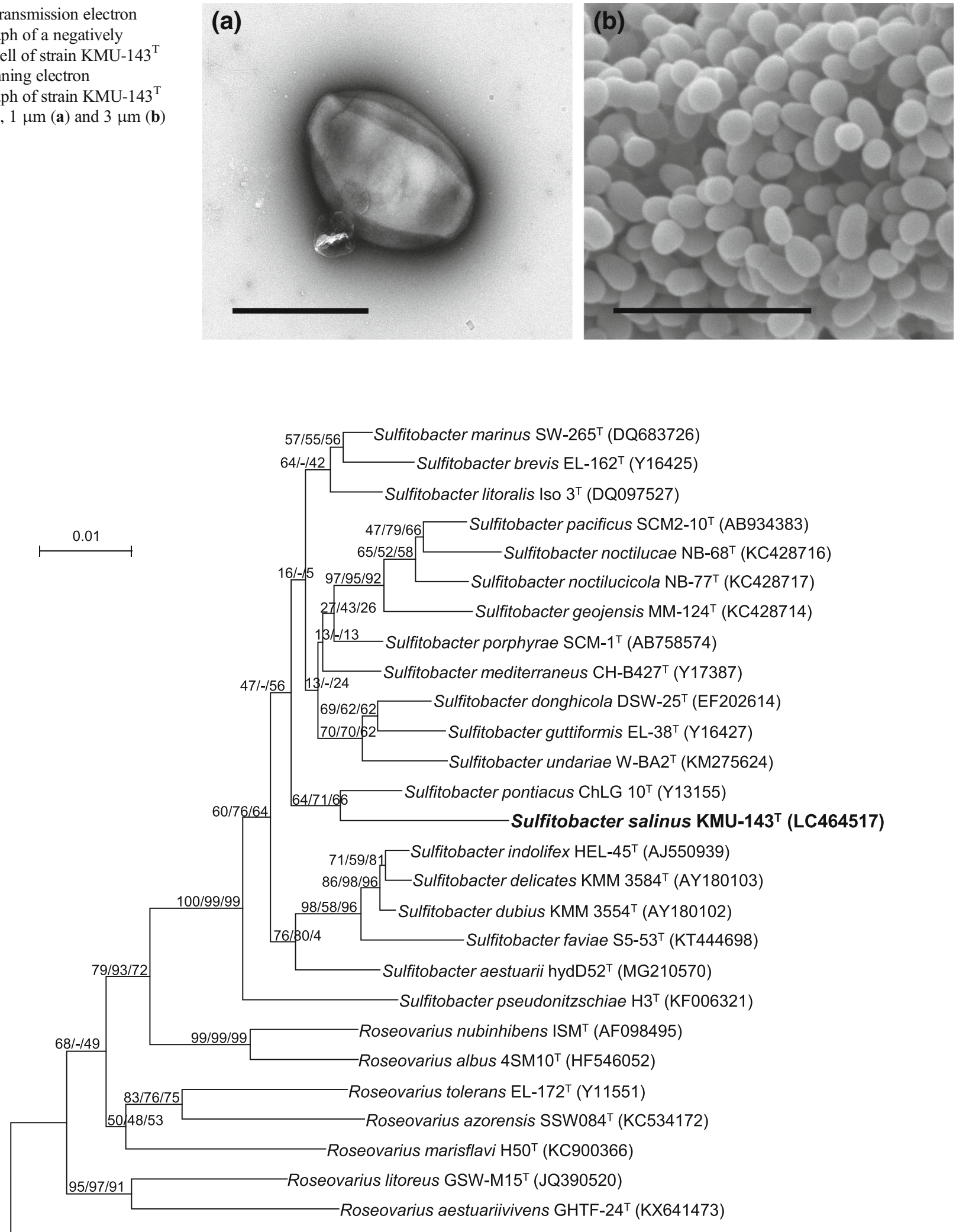

Rhodobacter capsulatus ATCC $11166^{\top}$ (D16428)

Fig. 2 Neighbor-joining tree of 16S rRNA gene sequence similarity. The phylogenetic positions of the strain KMU- $143^{\mathrm{T}}$ and representatives of closely related and other more distantly related species in the genus Sulfitobacter are shown. The tree was rooted using Rhodobacter capsulatus ATCC $11166^{\mathrm{T}}$ (D16428) as an outgroup. The numbers at the nodes indicate the percentages of the occurrence of the strain in 1000 bootstrapped trees. The sequence determined in this study is shown in bold. Bootstrap values from neighbor-joining, maximum-parsimony, and maximum-likelihood analyses are shown (NJ/MP/ML). Bar, $1 \%$ sequence divergence 
validly recognized Sulfitobacter members (Stackebrandt and Goebel 1994).

\section{Chemotaxonomic properties}

The major (> 10\%) cellular fatty acids of strain KMU-143 ${ }^{\mathrm{T}}$ were identified as $\mathrm{C} 16: 0$ and $\mathrm{C} 18: 1 \omega 7 c$ (Table 2). Based on the cellular fatty acid composition, strain KMU- $143^{\mathrm{T}}$ could be differentiated from the most closely related phylogenetic taxa S. pontiacus JCM $21789^{\mathrm{T}}$ and S. undariae KCTC $42200^{\mathrm{T}}$ through the differing proportions of iso-C18:0, C18:1 $\omega 7 c$, and 11-methyl C18:1 $\omega 7 c$ (Table 2) indicating that strain KMU- $143^{\mathrm{T}}$ probably represents a separate species of the genus Sulfitobacter. The polar lipids present in strain KMU$143^{\mathrm{T}}$ were composed of phosphatidylglycerol (PG), diphosphatidylglycerol (DPG), phosphatidylcholine (PC), an unidentified aminolipid (AL), and two unidentified lipids (L1-2) (Table 1 and Supplementary Fig. 1). The polar lipid profile of strain KMU-143 ${ }^{\mathrm{T}}$ was similar to that of S. pontiacus $\mathrm{JCM} 21789^{\mathrm{T}}$ and $S$. undariae $\mathrm{KCTC} 42200^{\mathrm{T}}$ in that the strain had PG, DPG, PC, AL, and L1-2. However, phosphatidylethanolamine (PE) was only found in S. pontiacus JCM $21789^{\mathrm{T}}$ and $S$. undariae KCTC $42200^{\mathrm{T}}$, and a L3 was only detected in

Table 2 Comparison of cellular fatty acids for strain KMU $-143^{\mathrm{T}}$ and closely related species

\begin{tabular}{llll}
\hline Fatty acid & 1 & 2 & 3 \\
C10:0 3-OH & 5.1 & 4.7 & 3.3 \\
C12:0 3-OH & $\operatorname{tr}$ & 1.6 & - \\
C14:0 & $\operatorname{tr}$ & - & $\operatorname{tr}$ \\
anteiso-C15:0 & - & $\operatorname{tr}$ & $\operatorname{tr}$ \\
C16:0 & 10 & 8.3 & 8.9 \\
C17:1 $\omega 8 c$ & - & $\operatorname{tr}$ & - \\
iso-C18:0 & - & - & 4.4 \\
C18:1 $\omega 7 c$ & 74.2 & 81.4 & 79.9 \\
C18:0 & 2.9 & 1.3 & 1.1 \\
11-methyl C18:1 $\omega 7 c$ & 5.1 & - & - \\
C19:0 cyclo $\omega 8 c$ & $\operatorname{tr}$ & - & - \\
Summed feature $2^{\mathrm{a}}$ & $\operatorname{tr}$ & $\operatorname{tr}$ & - \\
Summed feature $3^{\mathrm{b}}$ & $\operatorname{tr}$ & $\operatorname{tr}$ & 1.2 \\
Summed feature $5^{\mathrm{c}}$ & - & - & $\operatorname{tr}$ \\
Summed feature $7^{\mathrm{d}}$ & $\operatorname{tr}$ & $\operatorname{tr}$ & - \\
\hline
\end{tabular}

Strains: $1 \mathrm{KMU}-143^{\mathrm{T}}$ (Sulfitobacter salinus sp. nov.; present study), 2 Sulfitobacter pontiacus JCM $21789^{\mathrm{T}}, 3$ Sulfitobacter undariae KCTC $42200^{\mathrm{T}}$

All data are from this study. The data were typically obtained by GLC using the MIDI system

tr trace (less than 1.0\%), - not detected

${ }^{a}$ Summed feature 2 comprised C12:0 aldehyde ?

${ }^{\mathrm{b}}$ Summed feature 3 comprised C16:1 $\omega 7 c$ and/or C16:1 $\omega 6 c$

${ }^{\mathrm{c}}$ Summed feature 5 comprised ante-C18:0 and/or C18:2 $\omega 6,9 c$

${ }^{\mathrm{d}}$ Summed feature 7 comprised C19:1 $\omega 7 c$ and/or C19:1 $\omega 6 c$
S. pontiacus JCM $21789^{\mathrm{T}}$ (Table 1 and Supplementary Fig. 1). The sole isoprenoid quinone of the novel strain was ubiquinone-10 (Q-10), which is in accordance with the description of genus Sulfitobacter.

\section{Polyphasic taxonomic conclusion}

On the basis of the distinct phylogenetic position and combination of genotypic and phenotypic characteristics, strain KMU $-143^{\mathrm{T}}$ cannot be assigned to any previously recognized bacterial species and thus can be described as representing a novel species within a genus Sulfitobacter, Sulfitobacter salinus sp. nov.

\section{Description of Sulfitobacter salinus sp. nov.}

Sulfitobacter salinus (sa.li'nus. N.L. masc. adj. salinus salty)

Cells are Gram-stain-negative, strictly aerobic, oval-shaped that are mostly $0.9-1.0 \mu \mathrm{m}$ in width and $1.0-1.2 \mu \mathrm{m}$ in length. Cells lack flagella and are non-motile. Colonies grown on marine agar 2216 are circular and beige-pigmented after 3 days of incubation at $25^{\circ} \mathrm{C}$. Growth occurs at $10-37^{\circ} \mathrm{C}$ (optimum $25^{\circ} \mathrm{C}$ ), at $\mathrm{pH} 6.5-9.5$ (optimum $\mathrm{pH} 7.5$ ), and with 1.0 $6.0 \%(\mathrm{w} / \mathrm{v}) \mathrm{NaCl}$ (optimum 2.0\%). Positive for catalase and oxidase, but negative for reduction of nitrate. Tween 20 and Tween 80 are hydrolyzed, but agar, casein, DNA, gelatin, tyrosine, and urea are not. The reaction for $o$-nitrophenyl- $\beta$ D-galactopyranoside (ONPG) is positive, but VogesProskauer test, arginine dihydrolase, lysine decarboxylase, ornithine decarboxylase, tryptophan deaminase, citrate utilization, hydrogen sulfide production, and indole production tests are negative (API 20E). Acids are produced from esculin ferric citrate and 5-keto-gluconate, but not from amygdalin, arbutin, gentiobiose, melezitose, ribose, D-arabinose, Dturanose, D-lyxose, D-xylose, L-xylose, D-tagatose, D-fucose, L-fucose, D-arabitol, L-arabitol, gluconate, fructose, salicin, cellobiose, maltose, raffinose, methyl- $\beta$-D-xylopyranoside, glucose, lactose, galactose, mannose, melibiose, sucrose, trehalose, starch, glycogen, sorbose, rhamnose, sorbitol, methyl- $\alpha$-D-mannopyranoside, L-arabinose, methyl- $\alpha$-Dglucopyranoside, $\mathrm{N}$-acetyl-glucosamine, inulin, glycerol, erythritol, adonitol, dulcitol, inositol, mannitol, xylitol, and 2-keto-gluconate (API 50CH). Alkaline phosphatase, esterase (C4), leucine arylamidase, and naphthol-AS-BIphosphohydrolase are present, but valine arylamidase, trypsin, acid phosphatase, $\beta$-glucosidase, $\alpha$-glucosidase, $\beta$-galactosidase, $N$-acetyl- $\beta$-glucosaminidase, esterase lipase (C8), $\alpha$-galactosidase, lipase (C4), cystine arylamidase, $\alpha$-chymotrypsin, $\beta$-glucuronidase, $\alpha$-mannosidase, and $\alpha$-fucosidase are absent (API ZYM). Uses the organic substrate $\alpha$-D-glucose, Lalanine, L-serine, citric acid, L-malic acid, Tween 40, $\beta$-hydroxy-D,L-butyric acid, acetoacetic acid, and acetic acid, but not dextrin, gelatin, pectin, glycyl-L-proline, D-galacturonic 
acid, D-melibiose, D-fructose, D-arabitol, D-lactic acid methyl ester, $\beta$-methyl-D-glucoside, myo-inositol, L-arginine, Dgluconic acid, L-lactic acid, D-cellobiose, glycerol, L-aspartic acid, D-glucuronic acid, D-fucose, D-glucose-6-phosphate, Lglutamic acid, glucuronamide, $\alpha$-ketoglutaric acid, sucrose, $N$-acetyl- $\beta$-D-mannosamine, L-fucose, D-fructose-6-phosphate, L-histidine, mucic acid, D-turanose, $N$-acetyl-D-galactosamine, L-rhamnose, L-pyroglutamic acid, quinic acid, stachyose, $N$-acetylneuraminic acid, D-saccharic acid, D-raffinose, D-sorbitol, $p$-hydroxyphenylacetic acid, $\alpha$-D-lactose, D-mannose, D-mannitol, methyl pyruvate, $\gamma$-aminobutyric acid, D-maltose, $N$-acetyl-D-glucosamine, L-galactonic acid lactone, $\alpha$-hydroxybutyric acid, D-trehalose, D-galactose, Dsalicin, 3-methyl glucose, $\alpha$-ketobutyric acid, gentiobiose, Dmalic acid, propionic acid, D-aspartic acid, inosine, D-serine, bromosuccinic acid, and formic acid (Biolog GEN III MicroPlate). The predominant $(>10 \%)$ cellular fatty acids are $\mathrm{C} 16: 0$ and $\mathrm{C} 18: 1 \omega 7 c$. The sole respiratory isoprenoid quinone is ubiquinone-10. The major polar lipids are phosphatidylglycerol, diphosphatidylglycerol, phosphatidylcholine, an unidentified aminolipid, and two unidentified lipids. The $\mathrm{G}+\mathrm{C}$ content within the genomic DNA of the type strain is $56.1 \mathrm{~mol} \%$.

The type strain is KMU-143 ${ }^{\mathrm{T}}\left(=\mathrm{KCCM} 90322^{\mathrm{T}}=\mathrm{NBRC}\right.$ $113459^{\mathrm{T}}$ ), which was isolated from seawater collected at Hamdeok Beach, Jeju Island, Republic of Korea.

\section{Compliance with ethical standards}

Conflict of interest The author declares that he has no conflicts of interest.

Research involving human participants and/or animals This article does not contain any studies with human participants or animals performed by any of the author.

Informed consent N/A

\section{References}

Collins MD, Jones D (1981) A note on the separation of natural mixtures of bacterial ubiquinones using reverse-phase partition thin-layer chromatography and high performance liquid chromatography. J Appl Bacteriol 51:129-134

Colwell RR (1970) Polyphasic taxonomy of the genus Vibrio: numerical taxonomy of Vibrio cholerae, Vibrio parahaemolyticus, and related Vibrio species. J Bacteriol 104:410-433

Felsenstein J (1985) Confidence limits on phylogenies: an approach using the bootstrap. Evolution 39:783-791

Fitch WM (1971) Towards defining the course of evolution: minimum change for a specific tree topology. Syst Zool 20:406-416

Fukui Y, Abe M, Kobayashi M, Satomi M (2015) Sulfitobacter pacificus sp. nov., isolated from the red alga Pyropia yezoensis. Antonie Van Leeuwenhoek 107:1155-1163

Garrity GM, Brenner DJ, Krieg NR, Staley JT (2005) Bergey's manual of systematic bacteriology, vol 2, 2nd edn. Springer, New York
Giovannoni SJ, Rappé M (2000) Evolution, diversity, and molecular ecology of marine prokaryotes. In: Kirchman D (ed) Microbial ecology of the Oceans. Wiley, New York, pp 47-84

Hansen GH, Sørheim R (1991) Improved method for phenotypical characterization of marine bacteria. J Microbiol Methods 13:231-241

Hong Z, Lai Q, Luo Q, Jiang S, Zhu R, Liang J, Gao Y (2015) Sulfitobacter pseudonitzschiae sp. nov., isolated from the toxic marine diatom Pseudo-nitzschia multiseries. Int J Syst Evol Microbiol 65:95-100

Kimura M (1980) A simple method for estimating evolutionary rates of base substitutions through the comparative studies of sequence evolution. J Mol Evol 16:111-120

Komagata K, Suzuki K (1987) Lipid and cell-wall analysis in bacterial systematics. Methods Microbiol 19:161-207

Kumari P, Bhattacharjee S, Poddar A, Das SK (2016) Sulfitobacter faviae sp. nov., isolated from the coral Favia veroni. Int J Syst Evol Microbiol 66:3786-3792

Kwak MJ, Lee JS, Lee KC, Kim KK, Eom MK, Kim BK, Kim JF (2014) Sulfitobacter geojensis sp. nov., Sulfitobacter noctilucae sp. nov., and Sulfitobacter noctilucicola sp. nov., isolated from coastal seawater. Int J Syst Evol Microbiol 64:3760-3767

Labrenz M, Tindall BJ, Lawson PA, Collins MD, Schumann P, Hirsch P (2000) Staleya guttiformis gen. nov., sp. nov. and Sulfitobacter brevis sp. nov., alpha-3-Proteobacteria from hypersaline, heliothermal and meromictic Antarctic Ekho Lake. Int J Syst Evol Microbiol 50:303-313

Lane DJ (1991) In: Stackebrandt E, Goodfellow M (eds) 16S/23S rRNA sequencing. In Nucleic acid techniques in bacterial systematics. Wiley, Chichester, pp 115-175

Lewin RA, Lounsbery DM (1969) Isolation, cultivation and characterization of flexibacteria. J Gen Microbiol 58:145-170

Mesbah M, Premachandran U, Whitman WB (1989) Precise measurement of the $\mathrm{G}+\mathrm{C}$ content of deoxyribonucleic acid by highperformance liquid chromatography. Int J Syst Bacteriol 39:159167

Minnikin DE, O’Donnell AG, Goodfellow M, Alderson G, Athalye M, Schaal A, Parlett JH (1984) An integrated procedure for the extraction of bacterial isoprenoid quinines and polar lipids. J Microbiol Methods 2:233-241

Park JR, Bae JW, Nam YD, Chang HW, Kwon HY, Quan ZX, Park YH (2007) Sulfitobacter litoralis sp. nov., a marine bacterium isolated from the East Sea, Korea. Int J Syst Evol Microbiol 57:692-695

Park S, Jung YT, Won SM, Park JM, Yoon JH (2015) Sulfitobacter undariae sp. nov., isolated from a brown algae reservoir. Int J Syst Evol Microbiol 65:1672-1678

Park AY, Teeravet S, Pheng S, Lee JR, Kim SG, Suwannachart C (2018) Sulfitobacter aestuarii sp. nov., a marine bacterium isolated from a tidal flat of the Yellow Sea. Int J Syst Evol Microbiol 68:1771-1775

Power DA, Johnson JA (2009) Difco ${ }^{\mathrm{TM}}$ and BBL ${ }^{\mathrm{TM}}$ manual: manual of microbiological culture media, 2nd edn. Becton Dickinson and Company, Sparks, pp 359-360

Saitou N, Nei M (1987) The neighbor-joining method: a new method for reconstructing phylogenetic trees. Mol Biol Evol 4:406-425

Sasser M (1990) Identification of bacteria by gas chromatography of cellular fatty acids, MIDI Technical Note 101. MIDI Inc, Newark

Schädler S, Burkhardt C, Kappler A (2008) Evaluation of electron microscopic sample preparation methods and imaging techniques for characterization of cell-mineral aggregates. Geomicrobiol J 25:228 239

Sorokin DY (1995) Sulfitobacter pontiacus gen. nov., sp. nov. - a new heterotrophic bacterium from the Black Sea, specialized on sulfite oxidation. Microbiology (English translation of Mikrobiologiia) 64: 354-365

Stackebrandt E, Goebel BM (1994) Taxonomic note: a place for DNADNA reassociation and $16 \mathrm{~S}$ rRNA sequence analysis in the present species definition in bacteriology. Int J Syst Bacteriol 44:846-849 
Stackebrandt E, Murray RGE, Trüper HG (1988) Proteobacteria classis nov., a name for the phylogenetic taxon that includes the "purple bacteria and their relatives". Int J Syst Bacteriol 38:321-325

Suzuki K, Kaneko T, Komagata K (1981) Deoxyribonucleic acid homologies among coryneform bacteria. Int J Syst Bacteriol 31:131-138

Tamura K, Peterson D, Petersen N, Stecher G, Nei M, Kumar S (2011) MEGA5: molecular evolutionary genetics analysis using maximum likelihood, evolutionary distance, and maximum parsimony methods. Mol Biol Evol 28:2731-2739

Thompson JD, Gibson TJ, Plewniak F, Jeanmougin F, Higgins DG (1997) The CLUSTAL_X windows interface: flexible strategies for multiple sequence alignment aided by quality analysis tools. Nucleic Acids Res 25:4876-4882

Wang J, Chou S, Xu L, Zhu X, Dong N, Shan A, Chen Z (2015) High specific selectivity and membrane-active mechanism of the synthetic centrosymmetric $\alpha$-helical peptides with Gly-Gly pairs. Sci Rep 5:15963

Worliczek HL, Kämpfer P, Rosengarten R, Tindall RBJ, Busse HJ (2007) Polar lipid and fatty acid profiles-re-vitalizing old approaches as a modern tool for the classification of mycoplasmas? Syst Appl Microbiol 30:355-370

Yoon JH, Kang SJ, Lee MH, Oh TK (2007) Description of Sulfitobacter donghicola sp. nov., isolated from seawater of the East Sea in Korea, transfer of Staleya guttiformis Labrenz et al. 2000 to the genus Sulfitobacter as Sulfitobacter guttiformis comb. nov. and emended description of the genus Sulfitobacter. Int J Syst Evol Microbiol 57: 1788-1792

Yoon J, Lee KC, Lee JS (2016) Cribrihabitans pelagius sp. nov., a marine alphaproteobacterium isolated from seawater. Int J Syst Evol Microbiol 66:3195-3200

Yoon SH, Ha SM, Kwon S, Lim J, Kim Y, Seo H, Chun J (2017) Introducing EzBioCloud: a taxonomically united database of $16 \mathrm{~S}$ rRNA and whole genome assemblies. Int J Syst Evol Microbiol 67: 1613-1617

Publisher's note Springer Nature remains neutral with regard to jurisdictional claims in published maps and institutional affiliations. 